\title{
Oznaczanie metali w wybranych elementach środowiska w świetle obowiązujących uregulowań prawnych
}

\section{Determination of metals in selected elements of the environment in the context of applicable legal regulations}

\author{
Monika Gajec, Anna Król, Ewa Kukulska-Zając \\ Instytut Nafty i Gazu - Państwowy Instytut Badawczy
}

\begin{abstract}
STRESZCZENIE: Liczba substancji, które stanowią potencjalne ryzyko dla środowiska, wciąż rośnie, a ich dopuszczalne stężenia w poszczególnych elementach środowiska różnią się w zależności od kraju. Podczas prowadzenia oceny stanu środowiska przyrodniczego konieczne jest wykorzystywanie selektywnych i czułych metod analitycznych w celu oznaczania zawartości zanieczyszczeń na odpowiednim poziomie stężeń. Otrzymywanie miarodajnych wyników analitycznych jest możliwe przy zastosowaniu określonych procedur postępowania (m.in. posiadanie akredytacji przez laboratorium badawcze) i wykorzystaniu właściwych metodyk. Jeśli metodyki są m.in. powtarzalne, dokładne i czułe oraz zostały sprawdzone przez wieloletnie użytkowanie, mogą stać się metodykami referencyjnymi, co potwierdza dokładną weryfikację tych metodyk, a także gwarantuje otrzymanie dobrej jakości wyników. Jedną z grup substancji, dla których zawartości w elementach środowiska (w wodach, ściekach, glebach) muszą być monitorowane, są metale i metaloidy. Oznaczanie zawartości metali i metaloidów w próbkach środowiskowych jest wymagane prawnie, a dopuszczalne ich stężenia w elementach środowiska są limitowane i ulegają coraz większemu obniżeniu. W artykule opisano przegląd obowiązujących regulacji prawnych w zakresie oznaczania zawartości metali i metaloidów w różnych elementach środowiska (w wodach, ściekach oraz glebach). W artykule zebrano i przedstawiono dopuszczalne graniczne wartości stężeń poszczególnych metali i metaloidów w wodach powierzchniowych i podziemnych, ściekach przemysłowych oraz glebach, jak również metodyki referencyjne zalecane w badaniach i analizach zanieczyszczeń metalami w tych elementach środowiska. Przeprowadzony przegląd dopuszczalnych granicznych zawartości metali i metaloidów w wodach, ściekach oraz glebie pokazał, że wartości te są zróżnicowane w szerokim zakresie w zależności od rodzaju oznaczanego metalu oraz że istnieje konieczność oznaczania tego typu zanieczyszczeń na bardzo niskich poziomach stężeń. Przeprowadzony przegląd regulacji prawnych pokazał także, że zalecanymi metodykami referencyjnymi do oznaczania większości metali w próbkach środowiskowych są atomowa spektrometria emisyjna ze wzbudzeniem w plazmie indukowanej (ang. inductively coupled plasma optical emission spectrometry, ICP-OES), spektrometria mas z plazmą wzbudzoną indukcyjnie (ang. inductively coupled plasma mass spectrometry, ICP-MS) oraz absorpcyjna spektrometria atomowa (ang. atomic absorption spectrometry, AAS lub ASA). Są to nowoczesne metody instrumentalne, a wybór odpowiedniej metody powinien być uzależniony przede wszystkim od oznaczanych zakresów stężeń i oznaczanych analitów.
\end{abstract}

Słowa kluczowe: metale, regulacje prawne, ochrona środowiska, monitoring.

ABSTRACT: The number of substances that pose a potential risk to the environment is still growing, and their permissible concentrations vary in different countries. When conducting an environmental assessment, it is necessary to use selective and sensitive analytical methods to determine the content of contaminants at appropriate concentration levels. Obtaining reliable analytical results is possible using specific procedures (accreditation of the research laboratory) and using appropriate methodologies. If the methodologies are, for instance, repeatable, accurate and sensitive, and tested by many years of use, they can become reference methodologies, which proves that they are carefully examined and guarantee good results. One of the groups of substances for which the content in environmental elements (in water, wastewater, soils) must be monitored are metals and metalloids. The necessity to determine the content of this type of analytes in environmental samples is required by law, and the permissible concentrations in the environmental elements are decreasing. The article presents an overview of the most important Polish legal acts related to the content of metals and metalloids in various elements of the environment and provides the reference methodologies that should be used to determine this content. The review of the permissible limit values of metals and metalloids in water, sewage and soil showed that the values of acceptable metal and metalloid concentrations vary within a wide range depending on the type of analytes being measured and it is necessary to determine this type of contaminants at very low concentration levels. The conducted overview of regulations showed that it is necessary to determine metals in environmental samples at very low concentration levels. Reference methods recommended by the law for determining most metals

Autor do korespondencji: M. Gajec, e-mail:monika.gajec@inig.pl

Artykuł nadesłano do Redakcji 20.12.2018 r. Zatwierdzono do druku 18.04.2019 r. 
in environmental samples are: Inductively Coupled Plasma Optical Emission Spectrometry (ICP-OES), Inductively Coupled Plasma Mass Spectrometry (ICP-MS) and Atomic Absorption Spectrometry (AAS or ASA). Those are instrumental methods, each of them has both advantages and disadvantages. The choice of the appropriate method should depend on the determined concentration ranges, analytes determined, but also the costs of purchasing and using the apparatus.

Key words: metals, legal regulations, environmental protection, monitoring.

\section{Wstęp}

Jednym z ważniejszych zastosowań chemii analitycznej jest analityka środowiskowa, która obejmuje badania powietrza, gleb oraz wód. Najczęściej oznaczanymi analitami w próbkach tych elementów środowiska są metale i metaloidy. Oznaczanie tego typu analitów w próbkach środowiskowych przy użyciu metod klasycznych jest zwykle pracochłonne, wymaga wiele czasu oraz zastosowania dużych ilości toksycznych i kosztownych odczynników. Metody te są obecnie zastępowane technikami instrumentalnymi, które cechuje większa dokładność, powtarzalność i szybkość (Boczkaj, 2011). Techniki instrumentalne pozwalają również na jednoczesne oznaczanie składników występujących na poziomie makro oraz mikro, w próbkach o złożonych matrycach, z dużą dokładnością i precyzją. W zakresie oznaczeń substancji organicznych dominującą techniką analityczną jest chromatografia (gazowa i/lub cieczowa), w przypadku metali są to metody spektroskopowe (AAS, ICP-MS, ICP-OES, XRF), natomiast dla jonów nieorganicznych i organicznych - chromatografia jonowa. Coraz częściej w analizach zanieczyszczeń środowiska naturalnego wykorzystuje się także techniki łączone (Synak, 2010; Wieczorek, 2012).

W ostatnich latach ukazało się w Polsce wiele aktów prawnych, w których znaleźć można wymagania dotyczące oznaczania m.in. metali i metaloidów w poszczególnych elementach środowiska. Akty te podają wartości graniczne zawartości metali i metaloidów w elementach środowiska oraz metodyki referencyjne, które powinny być stosowane do ich oznaczania. Niejednokrotnie informacje o wartościach granicznych oraz zalecanych metodykach badawczych znajdują się jednak w gąszczu wymagań dotyczących oznaczania szeregu parametrów fizykochemicznych w próbkach środowiskowych. W związku z tym w dalszej części niniejszego artykułu omówiono w sposób syntetyczny najważniejsze uregulowania prawne dotyczące dopuszczalnej zawartości metali i metaloidów w próbkach wód, ścieków oraz gleb, jak również metodyki referencyjne rekomendowane do określania tych zawartości.

\section{Analiza uregulowań prawnych dotyczących zawartości metali i metaloidów w wodach, ściekach i glebie}

Dopuszczalne zawartości metali i metaloidów w próbkach wód powierzchniowych określa Rozporządzenie Ministra
Środowiska z dnia 21 lipca 2016 r. w sprawie sposobu klasyfikacji stanu jednolitych części wód powierzchniowych oraz środowiskowych norm jakości dla substancji priorytetowych (Dz.U. z 2016 r., poz. 1187). Rozporządzenie (Dz.U. z 2016 r., poz. 1187) określa sposób klasyfikacji stanu jednolitych części wód powierzchniowych, w tym sposób klasyfikacji:

- elementów fizykochemicznych, biologicznych i hydromorfologicznych, w oparciu o wchodzące w ich skład wskaźniki jakości, dla poszczególnych kategorii jednolitych części wód, uwzględniający różne typy wód powierzchniowych;

- stanu ekologicznego jednolitych części wód powierzchniowych w ciekach naturalnych, jeziorach lub innych zbiornikach naturalnych, wodach przejściowych oraz wodach przybrzeżnych, uwzględniający klasyfikację elementów fizykochemicznych, biologicznych i hydromorfologicznych;

- potencjału ekologicznego jednolitych części wód powierzchniowych sztucznych i silnie zmienionych, uwzględniający klasyfikację elementów fizykochemicznych, biologicznych i hydromorfologicznych;

- stanu chemicznego jednolitych części wód powierzchniowych i środowiskowe normy jakości dla substancji priorytetowych określonych w przepisach wydanych na podstawie art. 381 ust. 2 ustawy z dnia 18 lipca 2001 r. - Prawo wodne oraz dla innych zanieczyszczeń, służące klasyfikacji tego stanu.

Rozporządzenie (Dz.U. z 2016 r., poz. 1187) określa również sposób interpretacji wyników badań wskaźników jakości; sposób oceny stanu jednolitych części wód powierzchniowych; sposób prezentacji wyników klasyfikacji stanu ekologicznego jednolitych części wód powierzchniowych, potencjału ekologicznego jednolitych części wód powierzchniowych oraz stanu chemicznego jednolitych części wód powierzchniowych; częstotliwość dokonywania klasyfikacji poszczególnych elementów fizykochemicznych, biologicznych i hydromorfologicznych oraz klasyfikacji stanu ekologicznego, potencjału ekologicznego i stanu chemicznego jednolitych części wód powierzchniowych.

W załączniku nr 1 rozporządzenia (Dz.U. z 2016 r., poz. 1187) podane zostały wartości graniczne wskaźników jakości wód, w tym zawartości wapnia i magnezu, odnoszące się do jednolitych części wód powierzchniowych w ciekach naturalnych, takich jak kanał, struga, strumień, potok oraz rzeka, niewyznaczonych jako jednolite części wód sztuczne lub silnie zmienione, natomiast w załączniku nr 5 wartości graniczne 
wskaźników jakości wód odnoszące się do jednolitych części wód powierzchniowych, takich jak kanał, struga, strumień, potok oraz rzeka, wyznaczonych jako sztuczne lub silnie zmienione, w tym zbiorników zaporowych. Wartości te są określone dla różnych typów cieków oraz zależą od danej klasy jakości wody.

Wartości graniczne zawartości metali (wapnia i magnezu) określone dla poszczególnych typów cieków są bardzo zróżnicowane i mieszczą się w zakresie od 3,5 do 114,6 mg/l dla wapnia (Ca) oraz 0,7 do 40,4 mg/l dla magnezu (Mg) w zależności od klasy wody i typu cieku. Podane wartości graniczne zawartości metali dotyczą tylko wód klasy I i II, gdyż zgodnie z rozporządzeniem (Dz.U. z 2016 r., poz. 1187) dla wód klasy III, IV oraz V wartości granicznych się nie ustala. Mając powyższe na uwadze, metoda stosowana do analizy metali w próbkach wód powierzchniowych powinna umożliwić oznaczenie stężenia wapnia na poziomie $\leq 3,5 \mathrm{mg} / \mathrm{l}$ oraz stężenie magnezu na poziomie $\leq 0,7 \mathrm{mg} / \mathrm{l}$. Rozporządzenie (Dz.U. z 2016 r., poz. 1187) nie zaleca konkretnych metodyk referencyjnych do oznaczania metali w próbkach wód powierzchniowych. Metodyki referencyjne pomiarów i badań w ramach monitoringu jednolitych części wód powierzchniowych i podziemnych są podane w załączniku nr 7 Rozporządzenia Ministra Środowiska z dnia 19 lipca 2016 r. w sprawie form i sposobu prowadzenia monitoringu jednolitych części wód powierzchniowych i podziemnych (Dz.U. z 2016 r., poz. 1178). Rozporządzenie (Dz.U. z 2016 r., poz. 1178) dla oznaczenia zawartości większości metali zaleca trzy metodyki referencyjne, takie jak:

- atomowa spektrometria emisyjna ze wzbudzeniem w plazmie indukowanej (ang. inductively coupled plasma optical emission spectrometry, ICP-OES). W metodzie tej do atomizacji i wzbudzenia wykorzystuje się fale radiowe o wysokiej częstotliwości, które umożliwiają wytworzenie plazmy o wysokiej temperaturze (około $7000 \mathrm{~K}$ ). Dzięki niej związki chemiczne rozpadają się do atomów, a następnie ulegają wzbudzeniu, po czym emitują pochłoniętą energię w postaci promieniowania elektromagnetycznego, charakterystycznego dla danego pierwiastka (Kozak, 2010);

- spektrometria mas z plazmą wzbudzoną indukcyjnie (ang. inductively coupled plasma mass spectrometry, ICP-MS). Technika ta umożliwia szybką analizę wielopierwiastkową. Opiera się na jonizacji cząsteczek lub atomów, a następnie pomiarze stosunku masy do ładunku elektrycznego danego jonu. Jest to technika analityczna wykorzystująca plazmę jako źródło jonizacji i spektrometr mas jako analizator wygenerowanych w plazmie jonów. Pomiar za pomocą tej techniki charakteryzuje się dużą czułością i precyzją, możliwością jednoczesnego oznaczania wielu pierwiastków, selektywnością pozwalającą na oznaczanie poszczególnych izotopów danego pierwiastka w złożonych matrycach, niskimi granicami wykrywalności (dla roztworów na poziomie pg/l), uzyskanymi dzięki dużej wydajności jonizacji w plazmie, oraz szerokim zakresem prostoliniowości krzywych kalibracyjnych, dzięki czemu można w jednym pomiarze oznaczać zarówno pierwiastki śladowe, jak i makroskładniki (Malec i Borowski, 2014);

- absorpcyjna spektrometria atomowa (ang. atomic absorption spectrometry, AAS lub ASA). Metoda ta polega na wprowadzeniu próbki do aparatu atomizera, pomiarze absorbancji i obliczeniu na jej podstawie stężenia związku lub pierwiastka. Zastosowanie metody absorpcyjnej wymaga wykonania krzywej wzorcowej przed przystąpieniem do pomiarów. Niezbędne jest również posiadanie odpowiedniej lampy dla każdego oznaczanego pierwiastka. Omawiana metoda jest selektywna, ma bardzo dobrą czułość i można za jej pomocą oznaczyć około 70 pierwiastków. Niestety metoda ta jest relatywnie droga (duży koszt zakupu lamp), a samą analizę utrudniają interferencje i zakłócenia atomizacji oraz duże stężenia oznaczanych pierwiastków (Synak, 2010; Boczkaj, 2011).

Jak już wspomniano, metodyki referencyjne do oznaczania metali w próbkach wód powierzchniowych i podziemnych zostały wskazane w rozporządzeniu (Dz.U. z 2016 r., poz. 1178), natomiast wartości graniczne dla oznaczania zawartości metali w wodach podziemnych zostały zawarte w Rozporządzeniu Ministra Środowiska z dnia 21 grudnia 2015 r. w sprawie kryteriów i sposobu oceny stanu jednolitych części wód podziemnych (Dz.U. z 2016 r., poz. 85). Rozporządzenie (Dz.U. z 2016 r., poz. 85) określa kryteria i sposób oceny stanu jednolitych części wód podziemnych, w tym klasyfikację elementów fizykochemicznych, definicje klasyfikacji stanu ilościowego wód podziemnych oraz ich stanu chemicznego, sposób interpretacji wyników badań elementów fizykochemicznych i ilościowych, sposób prezentacji ich stanu, częstotliwość dokonywania oceny ich stanu oraz wartości progowe będące normami jakości środowiska wyrażonymi jako stężenie danej substancji zanieczyszczającej, grupy tych substancji lub substancji wyrażonej jako wskaźnik, które nie powinno być przekroczone z uwagi na ochronę środowiska oraz zdrowie ludzi.

Dopuszczalne wartości graniczne wskaźników jakości wód, w tym metali i metaloidów, odpowiednie dla danej klasy jakości wody podziemnej zostały zawarte w załączniku nr 1 do rozporządzenia (Dz.U. z 2016 r., poz. 85). Wartości graniczne zostały określone dla 23 metali, w tym dla metali ciężkich. Wartości graniczne określone dla pierwszej klasy jakości wód podziemnych mieszczą się w przedziale od $0,0005 \mathrm{mg} / 1$ (dla berylu - Be) do $60 \mathrm{mg} / \mathrm{l}$ (dla sodu - Na). Wartości graniczne 
określone dla wód podziemnych klasy II i III mieszczą się w przedziale od 0,001 mg/l (dla rtęci - Hg) do $200 \mathrm{mg} / \mathrm{l}$ (dla sodu - Na), dla wód klasy IV - w przedziale od 0,005 mg/l (dla $\mathrm{Hg}$ ) do $300 \mathrm{mg} / \mathrm{l}$ (dla $\mathrm{Na}$ ), natomiast dla wód klasy V dopuszczalne są graniczne zawartości metali $>0,005 \mathrm{mg} / \mathrm{l}$ (dla Hg) oraz $>300 \mathrm{mg} / 1$ (dla Na). Załącznik ten wskazuje także zakresy zawartości metali dla tła geochemicznego.

Zawartości metali i metaloidów zostały również określone prawnie, jako dopuszczalne wartości wskaźników zanieczyszczeń dla ścieków, w Rozporządzeniu Ministra Środowiska z dnia 18 listopada 2014 r. w sprawie warunków, jakie należy spełnić przy wprowadzaniu ścieków do wód lub do ziemi, oraz w sprawie substancji szczególnie szkodliwych dla środowiska wodnego (Dz.U. z 2014 r., poz. 1800). Rozporządzenie (Dz.U. z 2014 r., poz. 1800) określa:

- substancje szczególnie szkodliwe dla środowiska wodnego, powodujące zanieczyszczenie wód, które powinno być eliminowane, oraz substancje szczególnie szkodliwe dla środowiska wodnego, powodujące zanieczyszczenie wód, które powinno być ograniczane;

- warunki, jakie należy spełnić przy wprowadzaniu ścieków do wód lub do ziemi, w tym najwyższe dopuszczalne wartości zanieczyszczeń, oraz warunki, jakie należy spełnić w celu rolniczego wykorzystania ścieków;

- miejsce i minimalną częstotliwość pobierania próbek ścieków, metodyki referencyjne analizy i sposób oceny, czy ścieki odpowiadają wymaganym warunkom oraz

- najwyższe dopuszczalne wartości zanieczyszczeń dla ścieków z oczyszczalni ścieków bytowych i komunalnych oraz dla ścieków z oczyszczalni ścieków w aglomeracji.

W załączniku nr 4 rozporządzenia (Dz.U. z 2014 r., poz. 1800) zostały zawarte najwyższe dopuszczalne wartości wskaźników zanieczyszczeń dla niektórych substancji szczególnie szkodliwych dla środowiska wodnego. Określone w załączniku nr 4 (tabela I) najwyższe dopuszczalne wartości substancji szczególnie szkodliwych w ściekach przemysłowych, w tym metali ciężkich, dotyczą wartości tych wskaźników w dwóch rodzajach próbek, tj. średniej miesięcznej oraz średniej dobowej (dopuszcza się pobieranie próbek do oznaczania wartości wskaźników zanieczyszczeń w ściekach w sposób uproszczony, jeżeli można wykazać, że wyniki oznaczeń będą reprezentatywne dla ilości netto odprowadzanych zanieczyszczeń). W tabeli I załącznika nr 4 określono najwyższe dopuszczalne wartości wskaźników zanieczyszczeń dla dwóch metali (kadmu - Cd i rtęci - Hg), które są uzależnione od rodzaju działalności produkcyjnej, w trakcie której powstają ścieki. Dopuszczalne wartości graniczne dla rtęci wynoszą 0,06 mg/1 (próbka średnia dobowa) oraz 0,03 mg/l (próbka średnia miesięczna) i są określone dla zakładów produkcyjnych, których działalność nie jest związana z elektrolizą chlorków metali alkalicznych za pomocą elektrolizerów rtęciowych, ze stosowaniem katalizatorów rtęciowych: w produkcji chlorku winylu lub w innych procesach, z produkcją katalizatorów rtęciowych stosowanych $\mathrm{w}$ produkcji chlorku winylu, produkcją organicznych i nieorganicznych związków rtęci, z wyjątkiem katalizatorów rtęciowych stosowanych w produkcji chlorku winylu, z produkcją baterii galwanicznych zawierających rtęć, z przemysłem metali nieżelaznych oraz oczyszczaniem toksycznych odpadów zawierających rtęć. Najbardziej restrykcyjna dopuszczalna wartość określona dla Cd wynosi $0,05 \mathrm{mg} / \mathrm{l}$ i została określona dla przemysłu ciepłowniczego (próbka średnia dobowa). Natomiast tabela II załącznika nr 4 prezentuje najwyższe dopuszczalne wartości dla pozostałych wskaźników zanieczyszczeń dla ścieków, w tym zanieczyszczeń metalami. Podane w tabeli wartości graniczne dotyczą takich metali i metaloidów jak sód $(\mathrm{Na})$, potas $(\mathrm{K})$, żelazo $(\mathrm{Fe})$, glin $(\mathrm{Al})$, bar (Ba), beryl (Be), bor $(\mathrm{B})$, cynk (Zn), cyna $(\mathrm{Sn})$, chrom $(\mathrm{Cr})$, kobalt $(\mathrm{Co})$, miedź $(\mathrm{Cu})$, molibden $(\mathrm{Mo})$, nikiel $(\mathrm{Ni})$, ołów $(\mathrm{Pb})$, selen $(\mathrm{Se})$, srebro $(\mathrm{Ag})$, tal $(\mathrm{Tl})$, tytan (Ti), wanad (V), antymon (Sb) i arsen (As). Najwyższe dopuszczalne zawartości podane dla metali są zróżnicowane w zależności od rodzaju ścieków (przemysłowe, przemysłowe biologicznie rozkładalne) i rodzaju działalności. Wśród wymienionych metali najniższe dopuszczalne wartości zostały określone dla chromu $(0,05 \mathrm{mg} / \mathrm{l})$, najwyższe natomiast dla sodu (800 mg/l).

W załączniku nr 6 do rozporządzenia (Dz.U. z 2014 r., poz. 1800) podano z kolei najwyższe dopuszczalne wartości wskaźników zanieczyszczeń dla ścieków z oczyszczania gazów odlotowych, z procesu termicznego przekształcania odpadów wprowadzanych do wód. Najwyższe dopuszczalne wartości zostały określone dla siedmiu metali, tj. $\mathrm{Hg}, \mathrm{Cd}, \mathrm{Tl}, \mathrm{Pb}$, $\mathrm{Cr}, \mathrm{Cu}, \mathrm{Ni}, \mathrm{Zn}$, i ich związków w przeliczeniu na dany metal oraz dla arsenu i jego związków w przeliczeniu na As. Dla rtęci określona dopuszczalna wartość wynosi $0,03 \mathrm{mg} / \mathrm{l}$; dla kadmu i talu $0,05 \mathrm{mg} / 1$; dla arsenu $0,15 \mathrm{mg} / \mathrm{l}$; dla ołowiu $0,2 \mathrm{mg} / \mathrm{l}$; dla chromu, niklu i miedzi $0,5 \mathrm{mg} / 1$, natomiast dla cynku $1,5 \mathrm{mg} / 1$.

W badaniach próbek ścieków stosuje się metodyki referencyjne analizy próbek ścieków, określone w załączniku nr 12 do rozporządzenia (Dz.U. z 2014 r., poz. 1800). Rekomendowane metodyki referencyjne dla oznaczania metali w próbkach ścieków to głównie absorpcyjna spektrometria atomowa (ASA), spektrometria mas z plazmą wzbudzoną indukcyjnie (ICP-MS) oraz atomowa spektrometria emisyjna z plazmą wzbudzoną indukcyjnie (ICP-OES). Stosując wybrane metodyki referencyjne analizy, powinno się uwzględniać wykrywalność (czyli takie stężenie analitu, jakie można wykryć w badanej próbce daną metodą pomiarową, które odpowiada sygnałowi obliczonemu z wartości ślepej próby plus trzykrotność odchylenia standardowego; wyznacza 
się ją również jako średnią obliczoną z wyników oznaczeń minimum 10 próbek ślepych, po odrzuceniu wyników odbiegających, wykrytych testem Dixona), precyzję (czyli stopień zgodności wyników wielokrotnych analiz tej samej próbki w określonych warunkach; miarą precyzji jest odchylenie standardowe (SD) lub względne odchylenie standardowe (RSD)) oraz dokładność (rozumianą jako stopień zgodności między średnim wynikiem uzyskanym w szeregu powtórzeń a wartością prawdziwą mierzonej wartości).

W rozporządzeniu (Dz.U. z 2014 r., poz. 1800) zostały określone także dopuszczalne zawartości metali ciężkich w glebach, do których się wprowadza ścieki, w warstwie 0-30 cm (załącznik nr 9). Wartości te zostały określone dla siedmiu metali, tj. ołowiu, kadmu, rtęci, niklu, cynku, miedzi oraz chromu, w zależności od struktury gleby. Podane w załączniku nr 9 dopuszczalne zawartości metali mieszczą się w przedziale od $0,5 \mathrm{mg} / \mathrm{kg}$ suchej masy dla kadmu (w glebach bardzo lekkich) do $180 \mathrm{mg} / \mathrm{kg}$ suchej masy dla cynku (w glebach ciężkich).

Rozporządzenie (Dz.U. z 2014 r., poz. 1800) to nie jedyne rozporządzenie określające wymagania dotyczące dopuszczalnej zawartości metali w glebach (warstwa 0-30 cm; na obszarach, na których może być stosowane rolnicze wykorzystywanie ścieków). Dopuszczalne zawartości metali w glebach zostały w szerszym zakresie i bardziej szczegółowo zawarte w Rozporządzeniu Ministra Środowiska z dnia 1 września 2016 r. w sprawie sposobu prowadzenia oceny zanieczyszczenia powierzchni ziemi (Dz.U. z 2016 r., poz. 1395). Rozporządzenie (Dz.U. z 2016 r., poz. 1395) określa sposób prowadzenia oceny zanieczyszczenia powierzchni ziemi, w tym:

- substancje powodujące ryzyko szczególnie istotne dla ochrony powierzchni ziemi, ich dopuszczalne zawartości w glebie oraz dopuszczalne zawartości w ziemi, zróżnicowane dla poszczególnych właściwości gleby oraz grup gruntów, wydzielonych w oparciu o sposób ich użytkowania;

- szczegółowe wymagania dotyczące ustalania dopuszczalnej zawartości w glebie oraz dopuszczalnej zawartości w ziemi substancji powodującej ryzyko, innej niż wskazana powyżej, z uwzględnieniem analizy jej wpływu na zdrowie ludzi i stan środowiska;

- etapy identyfikacji terenów zanieczyszczonych (w szczególności sposób ustalenia działalności mogącej być przyczyną zanieczyszczenia na danym terenie obecnie lub w przeszłości; sposób ustalenia listy substancji powodujących ryzyko, których wystąpienie w glebie lub ziemi jest spodziewane ze względu na działalność mogącą być przyczyną zanieczyszczenia; źródła informacji istotne dla oceny zagrożenia zanieczyszczeniem gleby lub ziemi; warunki uznawania istniejących badań zanieczyszczenia gleby i ziemi za aktualne oraz etapy i sposób prowadzenia badań zanieczyszczenia gleby i ziemi);
- rodzaje działalności mogących z dużym prawdopodobieństwem powodować historyczne zanieczyszczenie powierzchni ziemi, wraz ze wskazaniem przykładowych dla tych działalności zanieczyszczeń;

- referencyjne metodyki wykonywania badań zanieczyszczenia gleby i ziemi;

- szczegółowe wymagania dotyczące oceny zanieczyszczenia gleby, ziemi lub wód gruntowych na terenie zakładu, gdzie jest lub była w przeszłości eksploatowana instalacja wymagająca uzyskania pozwolenia zintegrowanego, w celu zapewnienia identyfikacji każdego zanieczyszczenia przed uruchomieniem instalacji, w trakcie jej eksploatacji oraz po zamknięciu.

Załącznik nr 1 do rozporządzenia (Dz.U. z 2016 r., poz. 1395) określa substancje powodujące ryzyko szczególnie istotne dla ochrony powierzchni ziemi oraz dopuszczalne zawartości tych substancji w glebie, oraz dopuszczalne zawartości tych substancji w ziemi ( $\mathrm{mg} / \mathrm{kg}$ suchej masy części ziemistych gleby $(<2 \mathrm{~mm}))$. Dopuszczalne zawartości substancji powodujących ryzyko, w tym metali i metaloidów, zostały określone dla dwóch głębokości, tj. dla głębokości 0-0,25 m p.p.t. oraz dla głębokości przekraczającej $0,25 \mathrm{~m}$ p.p.t., z podziałem uwzględniającym grupy i podgrupy gruntów (wydzielone ze względu na sposób ich użytkowania w przypadku grup i ze względu na właściwości gleby określone dla grupy gruntów II) oraz w przypadku głębokości poniżej $0,25 \mathrm{~m}$ p.p.t. także wodoprzepuszczalność gleby i ziemi. Podane wartości graniczne zawartości metali są bardzo zróżnicowane, zależą od rodzaju gruntu i zostały ustalone dla 11 metali (Ba, Cr, Sn, Zn, Cd, Co, $\mathrm{Cu}, \mathrm{Mo}, \mathrm{Ni}, \mathrm{Pb}$ i Hg) oraz arsenu (As). Dopuszczalne zawartości metali i metaloidów jako substancji powodujących ryzyko mieszczą się w zakresie od 2,0 mg/kg suchej masy w przypadku kadmu oraz rtęci do $2000 \mathrm{mg} / \mathrm{kg}$ suchej masy w przypadku cynku dla głębokości 0-0,25 m p.p.t. Dla głębokości poniżej $0,25 \mathrm{~m}$ p.p.t. wartości te mieszczą się w przedziale od 3,0 mg/kg suchej masy w przypadku kadmu oraz rtęci do $3000 \mathrm{mg} / \mathrm{kg}$ suchej masy w przypadku cynku i baru.

Rozporządzenie (Dz.U. z 2016 r., poz. 1395) zawiera również załącznik nr 3, w którym określono referencyjne metodyki wykonywania badań zanieczyszczenia gleby i ziemi. Metodyki referencyjne dla oznaczania metali zostały określone w pkt 4 tego załącznika i są to przede wszystkim spektrometria mas z jonizacją w plazmie indukcyjnie sprzężonej (ICP-MS), atomowa spektrometria emisyjna z plazmą wzbudzoną indukcyjnie (ICP-OES) oraz absorpcyjna spektrometria atomowa $\mathrm{z}$ atomizacją bezpłomieniową (ETAAS) lub płomieniową (FAAS).

Należy dodać, że rozporządzenie (Dz.U. z 2016 r., poz. 1395) określa także rodzaje działalności mogących $\mathrm{z}$ dużym prawdopodobieństwem powodować historyczne zanieczyszczenie powierzchni ziemi, w tym rodzaje działalności 
Tabela 1. Zestawienie najniższych dopuszczalnych zawartości poszczególnych metali i metaloidów w próbkach środowiskowych w świetle obowiązujących wymagań prawnych

Table 1. Lowest permissible contents of individual metals and metalloids in environmental samples in the light of applicable legal requirements

\begin{tabular}{|c|c|c|}
\hline $\begin{array}{c}\text { Element środowiska } \\
\text { [jednostka] }\end{array}$ & Parametr & $\begin{array}{l}\text { Najniższa dopuszczalna } \\
\text { zawartość wskaźnika } \\
\text { określona prawnie }\end{array}$ \\
\hline \multirow{2}{*}{$\begin{array}{l}\text { Wody powierzchniowe } \\
\text { (Dz.U. z } 2016 \text { r., poz. 1187) } \\
\text { [mg/l] }\end{array}$} & Wapń (Ca) & 3,5 \\
\hline & Magnez (Mg) & 0,7 \\
\hline \multirow{27}{*}{$\begin{array}{l}\text { Wody podziemne } \\
\text { (Dz.U. z } 2016 \text { r., poz. 85) } \\
\text { [mg/l] }\end{array}$} & Antymon (Sb) & 0,005 \\
\hline & Arsen (As) & 0,01 \\
\hline & $\operatorname{Bar}(\mathrm{Ba})$ & 0,3 \\
\hline & Beryl (Be) & 0,0005 \\
\hline & Bor (B) & 0,5 \\
\hline & Chrom (Cr) & 0,01 \\
\hline & Cyna (Sn) & 0,02 \\
\hline & Cynk (Zn) & 0,05 \\
\hline & Glin (Al) & 0,1 \\
\hline & $\operatorname{Kadm}(\mathrm{Cd})$ & 0,001 \\
\hline & Kobalt (Co) & 0,02 \\
\hline & Magnez (Mg) & 30 \\
\hline & Mangan (Mn) & 0,05 \\
\hline & Miedź (Cu) & 0,01 \\
\hline & Molibden (Mo) & 0,003 \\
\hline & Nikiel (Ni) & 0,005 \\
\hline & Ołów (Pb) & 0,01 \\
\hline & Potas $(\mathrm{K})$ & 10 \\
\hline & Rtęć (Hg) & 0,001 \\
\hline & Selen $(\mathrm{Se})$ & 0,005 \\
\hline & Sód (Na) & 60 \\
\hline & Srebro (Ag) & 0,001 \\
\hline & Tal (Tl) & 0,001 \\
\hline & Tytan (Ti) & 0,01 \\
\hline & Wanad (V) & 0,004 \\
\hline & Wapń (Ca) & 50 \\
\hline & Żelazo (Fe) & 0,2 \\
\hline \multirow{11}{*}{$\begin{array}{l}\text { Ścieki } \\
\text { (Dz.U. z } 2014 \text { r., poz. 1800) } \\
\text { [mg/l] }\end{array}$} & Rtęć i jej związki w przeliczeniu na rtęć (Hg) & 0,03 \\
\hline & Kadm i jego związki w przeliczeniu na kadm (Cd) & 0,05 \\
\hline & Tal i jego związki w przeliczeniu na tal (Tl) & 0,05 \\
\hline & Arsen i jego związki w przeliczeniu na arsen (As) & 0,15 \\
\hline & Ołów i jego związki w przeliczeniu na ołów $(\mathrm{Pb})$ & 0,2 \\
\hline & Chrom i jego związki w przeliczeniu na chrom $(\mathrm{Cr})$ & 0,5 \\
\hline & Miedź i jej związki w przeliczeniu na miedź $(\mathrm{Cu})$ & 0,5 \\
\hline & Nikiel i jego związki w przeliczeniu na nikiel (Ni) & 0,5 \\
\hline & Cynk i jego związki w przeliczeniu na cynk (Zn) & 1,5 \\
\hline & Sód (Na) & 800 \\
\hline & Potas $(\mathrm{K})$ & 80 \\
\hline
\end{tabular}


cd. Tabela $\mathbf{1}$ / ect. Table 1

\begin{tabular}{|c|c|c|}
\hline $\begin{array}{c}\text { Element środowiska } \\
\text { [jednostka] }\end{array}$ & Parametr & $\begin{array}{l}\text { Najniższa dopuszczalna } \\
\text { zawartość wskaźnika } \\
\text { określona prawnie }\end{array}$ \\
\hline \multirow{21}{*}{$\begin{array}{l}\text { Ścieki } \\
\text { (Dz.U. z } 2014 \text { r., poz. 1800) } \\
\text { [mg/l] }\end{array}$} & Żelazo ogólne (Fe) & 10 \\
\hline & Glin $(\mathrm{Al})$ & 3 \\
\hline & Antymon (Sb) & 0,3 \\
\hline & Arsen (As) & 0,1 \\
\hline & $\operatorname{Bar}(\mathrm{Ba})$ & 2 \\
\hline & Beryl (Be) & 1 \\
\hline & Bor (B) & 1 \\
\hline & Cynk (Zn) & 2 \\
\hline & Cyna (Sn) & 1 \\
\hline & Chrom $\left(\mathrm{Cr}^{6+}\right)$ & 0,05 \\
\hline & Chrom ogólny $(\mathrm{Cr})$ & 0,5 \\
\hline & Kobalt (Co) & 0,1 \\
\hline & Miedź (Cu) & 0,1 \\
\hline & Molibden (Mo) & 1 \\
\hline & Nikiel (Ni) & 0,1 \\
\hline & Ołów (Pb) & 0,1 \\
\hline & Selen $(\mathrm{Se})$ & 1 \\
\hline & Srebro (Ag) & 0,1 \\
\hline & Tal (Tl) & 1 \\
\hline & Tytan (Ti) & 1 \\
\hline & Wanad (V) & 2 \\
\hline \multirow{7}{*}{$\begin{array}{l}\text { Gleby } \\
\text { (Dz.U. z } 2014 \text { r., poz. 1800) } \\
\text { [mg/kg s.m.] }\end{array}$} & Ołów (Pb) & 20 \\
\hline & $\operatorname{Kadm}(\mathrm{Cd})$ & 0,5 \\
\hline & Rtęć (Hg) & 0,7 \\
\hline & Nikiel (Ni) & 10 \\
\hline & Cynk (Zn) & 60 \\
\hline & Miedź (Cu) & 20 \\
\hline & Chrom (Cr) & 30 \\
\hline \multirow{12}{*}{$\begin{array}{l}\text { Gleby } \\
\text { (Dz.U. z } 2016 \text { r., poz. 1395) } \\
\text { [mg/kg s.m.] }\end{array}$} & Arsen (As) & 10 \\
\hline & $\operatorname{Bar}(\mathrm{Ba})$ & 200 \\
\hline & Chrom (Cr) & 150 \\
\hline & Cyna (Sn) & 10 \\
\hline & Cynk (Zn) & 300 \\
\hline & $\operatorname{Kadm}(\mathrm{Cd})$ & 2 \\
\hline & Kobalt (Co) & 20 \\
\hline & Miedź (Cu) & 100 \\
\hline & Molibden (Mo) & 10 \\
\hline & Nikiel (Ni) & 100 \\
\hline & Ołów $(\mathrm{Pb})$ & 100 \\
\hline & Rtęć (Hg) & 2 \\
\hline
\end{tabular}


obejmujące eksploatację wybranych rodzajów instalacji mogących powodować znaczne zanieczyszczenie poszczególnych elementów przyrodniczych albo środowiska jako całości, rodzaje działalności stanowiące wybrane rodzaje przedsięwzięć mogących znacząco oddziaływać na środowisko oraz inne rodzaje działalności. Dla wskazanych działalności zostały wymienione przykładowe zanieczyszczenia, wśród których znajdują się również metale i metaloidy.

Przeprowadzona analiza uregulowań prawnych w zakresie oznaczania metali i metaloidów w próbkach wód, ścieków oraz gleb pokazuje, że dopuszczalne zawartości poszczególnych metali w tych próbkach są bardzo zróżnicowane i zależą od wielu czynników, np. klasy jakości wody i rodzaju cieku w przypadku oznaczania metali w próbkach wód powierzchniowych czy grupy gruntów w przypadku oznaczania tych zanieczyszczeń w próbkach gleb. Należy jeszcze dodać, że obecnie wymagane jest oznaczanie metali w próbkach środowiskowych na bardzo niskich poziomach stężeń. Mając powyższe na uwadze, w tabeli 1 przedstawiono w sposób syntetyczny określone prawem najniższe dopuszczalne zawartości poszczególnych metali i metaloidów w próbkach danego rodzaju matrycy. Zawartości te mieszczą się w zakresie od 0,0005 mg/1 dla berylu w próbkach wód podziemnych do $800 \mathrm{mg} / \mathrm{l}$ dla sodu w próbkach ścieków oraz od $0,5 \mathrm{mg} / \mathrm{kg}$ s.m. dla kadmu do $300 \mathrm{mg} / \mathrm{kg}$ s.m. dla cynku w próbkach gleb.

Jak już wspomniano, uregulowania prawne obejmujące swym zakresem oznaczanie metali i metaloidów w próbkach środowiskowych poza określeniem wartości granicznych dla poszczególnych analitów wskazują również metodyki referencyjne dla oznaczania tych wartości wraz z podaniem odpowiednich norm lub procedur. W związku z tym w tabeli 2 zebrano metodyki referencyjne do oznaczania metali i metaloidów w próbkach wód, ścieków oraz gleb, zalecane przez obowiązujące akty prawne.

Dane przedstawione w tabeli 2 pokazują, że do oznaczania metali i metaloidów na wymaganych prawnie niskich poziomach stężeń zalecane są nowoczesne techniki instrumentalne, które pozwalają na oznaczenie w stosunkowo krótkim czasie szerokiego spektrum metali. Należy jednak pamiętać, że metodyka referencyjna powinna być dobrana w pierwszej kolejności spośród metodyk znormalizowanych (norm), pod warunkiem że są spełnione wymagania odnośnie do granicy oznaczalności oraz niepewności pomiaru metody.

Tabela 2. Referencyjne metodyki rekomendowane do oznaczania metali w próbkach wód powierzchniowych, wód podziemnych, ścieków i gleb

Table 2. Reference methodologies recommended for the determination of metals in samples of surface water, ground water, wastewater and soils

\begin{tabular}{|c|c|c|}
\hline \multicolumn{3}{|c|}{ Wody powierzchniowe i podziemne (Dz.U. z 2016 r., poz. 1178) } \\
\hline Substancja powodująca ryzyko & Metodyka referencyjna & Norma/procedura \\
\hline $\begin{array}{l}\text { As, } \mathrm{Ba}, \mathrm{Cr}, \mathrm{Zn}, \mathrm{Cu}, \mathrm{Al}, \mathrm{Mo}, \mathrm{Ag} \\
\mathrm{Tl}, \mathrm{Ti}, \mathrm{V}, \mathrm{Be}, \mathrm{Co}, \mathrm{Sn}, \mathrm{Cd}, \mathrm{Pb}, \mathrm{Ni} \\
\text { Fe, Mn }\end{array}$ & $\begin{array}{l}\text { Atomowa spektrometria emisyjna z plazmą } \\
\text { wzbudzoną indukcyjnie (ICP-OES) }\end{array}$ & Procedura badawcza na podstawie PN-EN ISO 11885 \\
\hline $\begin{array}{l}\text { As, Ba, Cr, Zn, Cu, Al, Mo, Ag, } \\
\text { Ti, V, Co, Sn, Cd, Pb, Ni, Fe, Mn }\end{array}$ & $\begin{array}{l}\text { Absorpcyjna spektrometria atomowa (ASA) } \\
\text { z atomizacją bezpłomieniową }\end{array}$ & Procedura badawcza na podstawie PN-EN ISO 15586 \\
\hline As & $\begin{array}{l}\text { Absorpcyjna spektrometria atomowa (ASA) } \\
\text { z generacją wodorków }\end{array}$ & Procedura badawcza na podstawie PN-EN ISO 11969 \\
\hline $\begin{array}{l}\text { As, Ba, Cr, } \mathrm{Zn}, \mathrm{Cu}, \mathrm{Al}, \mathrm{Mo}, \mathrm{Ag}, \\
\text { Tl, Ti, V, Be, Co, Sn, Cd, Pb, Ni, } \\
\text { Fe, Mn }\end{array}$ & $\begin{array}{l}\text { Spektrometria mas z plazmą wzbudzoną in- } \\
\text { dukcyjnie (ICP-MS) }\end{array}$ & Procedura badawcza na podstawie PN-EN ISO 17294-2 \\
\hline \multirow{2}{*}{$\begin{array}{l}\mathrm{Cr}^{6+} \\
\mathrm{Fe}\end{array}$} & \multirow{2}{*}{ Spektrofotometryczna } & Procedura badawcza na podstawie PN-EN ISO 18412 \\
\hline & & Procedura badawcza na podstawie PN-ISO 6332 \\
\hline $\mathrm{Cr}^{6+}$ & $\begin{array}{l}\text { Absorpcyjna spektrometria atomowa, po } \\
\text { strąceniu } \mathrm{Cr}^{3+} \text { (ASA) }\end{array}$ & Procedura badawcza \\
\hline $\mathrm{Cr}^{6+}$ & Chromatografia jonowa (IC) & Procedura badawcza na podstawie PN-EN ISO 10304-3 \\
\hline $\mathrm{Cr}$ & $\begin{array}{l}\text { Absorpcyjna spektrometria atomowa } \mathrm{z} \text { ato- } \\
\text { mizacją płomieniową lub bezpłomieniową }\end{array}$ & Procedura badawcza na podstawie PN-EN 1233 \\
\hline \multirow{2}{*}{$\begin{array}{l}\mathrm{Zn} \\
\mathrm{Fe}, \mathrm{Mn}\end{array}$} & \multirow{2}{*}{$\begin{array}{l}\text { Absorpcyjna spektrometria atomowa (ASA) } \\
\mathrm{z} \text { atomizacją płomieniową }\end{array}$} & Procedura badawcza na podstawie PN-ISO 8288 \\
\hline & & Procedura badawcza \\
\hline $\mathrm{Al}$ & $\begin{array}{l}\text { Absorpcyjna spektrometria atomowa (ASA) } \\
\mathrm{z} \text { atomizacją płomieniową }\end{array}$ & Procedura badawcza na podstawie PN-EN ISO 12020 \\
\hline \multirow[b]{2}{*}{$\mathrm{Sn}, \mathrm{Hg}$} & \multirow{2}{*}{$\begin{array}{l}\text { Atomowa spektrometria fluorescencyjna } \\
\text { (ASF) }\end{array}$} & Procedura badawcza \\
\hline & & $\begin{array}{l}\text { Procedura badawcza na podstawie PN-EN ISO } 17852 \text { lub } \\
\text { inna procedura badawcza z uwzględnieniem prekoncentracji }\end{array}$ \\
\hline
\end{tabular}


cd. Tabela 2 / ect. Table 2

\begin{tabular}{|c|c|c|}
\hline \multicolumn{3}{|c|}{ Ścieki (Dz.U. z 2014 r., poz. 1800) } \\
\hline Nazwa wskaźnika & Metody analiz i pomiarów & Norma \\
\hline $\begin{array}{l}\mathrm{Sb}, \mathrm{Cr}, \mathrm{Zn}, \mathrm{Al}, \mathrm{Cd}, \mathrm{Co}, \mathrm{Cu}, \mathrm{Mo} \\
\mathrm{Ni}, \mathrm{Pb}, \mathrm{Ag}, \mathrm{Tl}, \mathrm{Ti}, \mathrm{V}, \mathrm{Fe}\end{array}$ & \multirow{11}{*}{$\begin{array}{l}\text { Absorpcyjna spektroskopia atomowa (ASA) } \\
\mathrm{z} \text { atomizacją bezpłomieniową }\end{array}$} & PN-EN ISO 15586 \\
\hline $\mathrm{Ba}$ & & PN-C-04570-5 \\
\hline $\mathrm{Cr}$ & & PN-EN 1233 \\
\hline $\mathrm{Cr}^{6+}$ & & PN-C-04604-8 \\
\hline $\mathrm{Zn}, \mathrm{Cd}, \mathrm{Co}, \mathrm{Cu}, \mathrm{Ni}, \mathrm{Pb}$ & & PN-ISO 8288 \\
\hline $\mathrm{Cd}$ & & PN-EN ISO 5961 \\
\hline $\mathrm{K}, \mathrm{Na}$ & & PN-ISO 9964-1/Ak \\
\hline $\mathrm{Na}$ & & PN-ISO 9964-2/Ak \\
\hline $\mathrm{K}, \mathrm{Na}$ & & PN-ISO 9964-3/Ak \\
\hline \multirow{2}{*}{$\mathrm{Hg}$} & & PN-EN 1483 \\
\hline & & PN-EN 12338 \\
\hline $\begin{array}{l}\mathrm{Sb}, \mathrm{Ba}, \mathrm{Be}, \mathrm{Cr}, \mathrm{Sn}, \mathrm{Zn}, \mathrm{Al}, \mathrm{Cd} \\
\mathrm{Co}, \mathrm{Cu}, \mathrm{Mo}, \mathrm{Ni}, \mathrm{Pb}, \mathrm{K}, \mathrm{Na}, \mathrm{Ag}, \\
\text { Tl, V, Fe }\end{array}$ & $\begin{array}{l}\text { Atomowa spektrometria emisyjna z plazmą } \\
\text { wzbudzoną indukcyjnie (ICP-OES) }\end{array}$ & PN-EN ISO 11885 \\
\hline $\begin{array}{l}\mathrm{Sb}, \mathrm{Be}, \mathrm{Cr}, \mathrm{Sn}, \mathrm{Zn}, \mathrm{Cd}, \mathrm{Co}, \mathrm{Cu} \\
\mathrm{Mo}, \mathrm{Ni}, \mathrm{Pb}, \mathrm{K}, \mathrm{Na}, \mathrm{Ag}, \mathrm{Tl}, \mathrm{V}\end{array}$ & $\begin{array}{l}\text { Spektrometria mas z plazmą wzbudzoną in- } \\
\text { dukcyjnie (ICP-MS) }\end{array}$ & PN-EN ISO 17294-2 \\
\hline
\end{tabular}

\section{Podsumowanie}

Analizy wód, ścieków i gleb w zakresie oznaczania zawartości m.in. metali i metaloidów to najczęściej prowadzone badania w laboratoriach środowiskowych i kontrolno-pomiarowych. Jakość tych badań ma istotny wpływ na wydawane decyzje środowiskowe i technologiczne oraz na dokonywanie oceny stanu środowiska naturalnego. Obecnie dopuszczalne zawartości w wodach, ściekach i glebach metali i metaloidów określone są w kilku rozporządzeniach (Dz.U. z 2014 r., poz. 1800; Dz.U. z 2016 r., poz. 85; Dz.U. z 2016 r., poz. 1187; Dz.U. z 2016 r., poz. 1395). Wartości dopuszczalnych stężeń metali i metaloidów wskazane $\mathrm{w}$ tych rozporządzeniach są zróżnicowane w szerokim zakresie - od 0,0005 mg/l w próbkach wód podziemnych do $800 \mathrm{mg} / \mathrm{l}$ w próbkach ścieków oraz od $0,5 \mathrm{mg} / \mathrm{kg}$ s.m. do $300 \mathrm{mg} / \mathrm{kg}$ s.m. w próbkach gleb, w zależności od rodzaju oznaczanej substancji. Jako metody referencyjne do oznaczania metali i metaloidów w próbkach wód, ścieków oraz gleb w znacznej mierze zalecane są metody instrumentalne, takie jak przede wszystkim absorpcyjna spektrometria atomowa (ASA), spektrometria mas z plazmą wzbudzoną indukcyjnie (ICP-MS) oraz spektrometria emisyjna ze wzbudzeniem w plazmie indukcyjnie sprzężonej (ICP-OES).

Artykuł powstał na podstawie pracy statutowej pt.: Doskonalenie metody oznaczania metali na potrzeby prowadzenia oceny stanu zanieczyszczenia środowiska - praca INiG - PIB na zlecenie MNiSW; nr zlecenia: 0025/GE/18/01, nr archiwalny: DK-4100-25/18.

\section{Literatura}

Boczkaj G., 2011. Przygotowanie próbki do wykonania oznaczeń zawartości metali ciężkich w produktach technicznych. Gdańsk. $<$ https://chem.pg.edu.pl/documents/175628/48453333/cw9b.pdfs (dostęp: październik 2018).

Kozak M., 2010. Zastosowanie optycznej spektrometrii emisyjnej, ze wzbudzeniem w plazmie indukowanej w badaniach przetworów naftowych. Nafta-Gaz, 7: 606-612.

Malec A., Borowski G., 2014. Zastosowanie metod spektroskopowych do oznaczania zawartości pierwiastków i jonów. Inżynieria Ekologiczna, 40: 228-238. DOI: 10.12912/2081139X.85.

Synak E., 2010. Monitoring i analityka zanieczyszczeń w środowisku. Gdańsk: Wydawnictwo Uniwersytetu Gdańskiego.

Wieczorek A., 2012. Ocena możliwości wykorzystania techniki spektrometrii rentgenowskiej z dyspersją fali do badania zawartości szkodliwych i kancerogennych metali ciężkich w produktach naftowych. Nafta-Gaz, 10: 700-707.

\section{Akty prawne i normatywne}

Rozporządzenie Ministra Środowiska z dnia 18 listopada 2014 r. w sprawie warunków, jakie należy spełnić przy wprowadzaniu ścieków do wód lub do ziemi, oraz w sprawie substancji szczególnie szkodliwych dla środowiska wodnego (Dz.U. z 2014 r., poz. 1800).

Rozporządzenie Ministra Środowiska z dnia 21 grudnia 2015 r. w sprawie kryteriów i sposobu oceny stanu jednolitych części wód podziemnych (Dz.U. z 2016 r., poz. 85).

Rozporządzenie Ministra Środowiska z dnia 19 lipca 2016 r. w sprawie form i sposobu prowadzenia monitoringu jednolitych części wód powierzchniowych i podziemnych (Dz.U. z 2016 r., poz. 1178). 


\section{NAFTA-GAZ}

Rozporządzenie Ministra Środowiska z dnia 21 lipca 2016 r. w sprawie sposobu klasyfikacji stanu jednolitych części wód powierzchniowych oraz środowiskowych norm jakości dla substancji priorytetowych (Dz.U. z 2016 r., poz. 1187).

Rozporządzenie Ministra Środowiska z dnia 1 września 2016 r. w sprawie sposobu prowadzenia oceny zanieczyszczenia powierzchni ziemi (Dz.U. z 2016 r., poz. 1395).

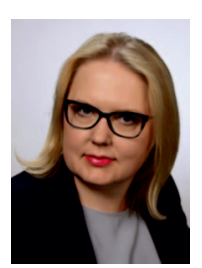

Dr Anna KRÓL

Adiunkt w Zakładzie Ochrony Srodowiska

Instytut Nafty i Gazu - Państwowy Instytut Badawczy

ul. Lubicz 25 A

31-503 Kraków

E-mail:anna.krol@inig.pl

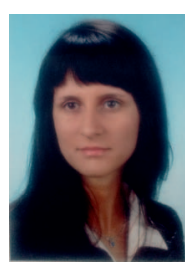

Mgr Monika Gajec

Główny specjalista inżynieryjno-techniczny

w Zakładzie Ochrony Środowiska

Instytut Nafty i Gazu - Państwowy Instytut Badawczy ul. Lubicz 25 A

31-503 Kraków

E-mail: monika.gajec@inig.pl

Dr Ewa KUKULSKA-ZAJAC

Adiunkt; kierownik Zakładu Ochrony Środowiska Instytut Nafty i Gazu - Państwowy Instytut Badawczy ul. Lubicz 25 A

31-503 Kraków

E-mail:kukulska@inig.pl

\section{MIEDZYNARODOWA KONFERENCJA NAUKOWO-TECHNICZNA}

\section{SRODKI SMAROWE 2019 \\ ZAKOPANE, 15-17 MAJA $2019 \mathrm{r}$}

\section{ZAPRASZAMY}

- producentów środków smarowych: olejów, smarów i cieczy technologicznych

- producentów olejów bazowych

- producentów i dystrybutorów komponentów do środków smarowych

- pracowników działów $B+R$

- kadrę zarz ądzającą gospodarką smarową

- przedstawicieli uczelni i instytutów badawczych

- producentów i dostawców sprzętu laboratoryjnego

- użytkowników środków smarowych

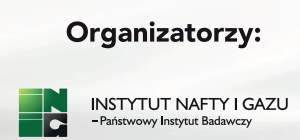

\section{CEC POLSKA} Stowarzyszenie Wspópracy Przemystu
Naftowego i Samochodowego

Sponsor Złoty:

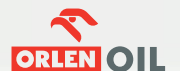

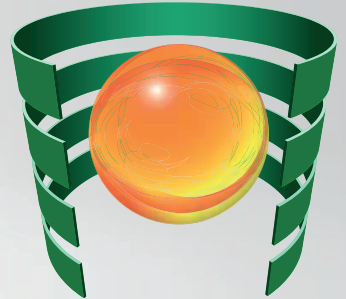

Główny Partner Technologiczny:

Patroni Medialni:

Nafta-Gaz

SLLTOS

\section{preemysl chemictiny}

Sponsorzy Brązowi:
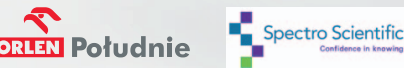

\section{REJESTRACJA UCZESTNIKÓW:}

Magdalena Skórska-Sawina

tel.: 126177664

e-mail: srodkismarowe@inig.pl

www.srodkismarowe.inig.pl 